\title{
Researching fakes: practicing anthropology out of the corner of one's eye
}

By Magdalena Crăciun (University College London)

This paper discusses the style of anthropological inquiry forged through attempts at grasping the elusive presence of fake branded goods. Although they are morally and legally combated, and culturally and socially derided, fake branded goods are ubiquitous. An anthropologist interested in researching ways in which people do find a place for the fakes in their lives is nevertheless challenged in various ways. In brief, the ubiquitous becomes elusive, and the anthropologist is suspected of secretly laughing at and condemning people, practices and objects. Reflecting upon the particularities and constraints of such a field experience, this paper argues for the advantages of practicing anthropology out of the corner of one's eye. This is a method of capturing something that is not discussed straightforwardly, something that quickly turns from visible into invisible. At the same time, it is an attitude in which discretion and respect mingle with diffidence.

\section{Introduction}

Fake branded goods are caught in the binary logic of the original and the copy, and its built-in judgmental bias that regards one side as better so that the other side becomes denigrated. It implies that originals are better than copies or, as Baudrillard (1983) or Eco (1986) claim, the exact opposite, which is still the inverse of the same logic. Nevertheless, despite the fact that these goods are morally and legally combated, and culturally and socially derided, they are ubiquitous. Moreover, although public culture provides discriminating value markings of these commodities, they compete with private understandings and classifications by individuals and small networks, who might belong to other value systems and cultures (Douglas and Isherwood 1979, Kopytoff 1986).

For my $\mathrm{PhD}$ fieldwork, I set out to investigate the place of fake brands in lives lived in the margins of Europe, a choice of area related to my background and previous knowledge of commodity chains linking Turkey and Romania. My project was orientated towards capturing ethnographic snapshots of a reality marginalised, if not excluded, from the mainstream conceptualisation of faking and fakes. My intention was to work both with people who manufacture for a generic 'west' and with those who consume such products, and compare their (alternative) modes of relating to fake branded goods. Drawing on Appadurai's insight that 'from a methodological point of view it is the thing-in-motion that illuminates their human and social context' (1986:5, emphasis in original), I planned to focus on the commodity phase and on the subsequent singularisation stages of these objects, and thus designed a multi-sited research to 'follow the thing' (Marcus 1995) in and through different contexts. I chose three sites, i.e. spaces of production, distribution and consumption, and spent 19 
months doing fieldwork, living in and commuting between Istanbul (the main regional producer), 'Europa' market on the outskirts of Bucharest (considered the source of most of the counterfeited goods on the Romanian market), and a provincial Romanian town (in which 'Europa' clothing predominates).

This paper discusses the style of anthropological inquiry forged through attempts at grasping ways in which people do find a place for the fake branded products in their lives. A researcher embarked on such a project is challenged in various ways. In a nutshell, the ubiquitous becomes elusive, and the anthropologist is suspected of secretly laughing at and condemning people, practices and objects. As difficult as it is to explain and carry out the anthropological project under normal circumstances, it became even more so under those in which I found myself. The constraining relational and material conditions set by my fields played an essential role in contextualising my agency as an anthropologist (Kalir 2006). Without claiming that my problems are unique or that anthropologists working on different projects would never have to confront such dilemmas, and argue for the advantages of practicing anthropology 'out of the corner of my eye'. I hope that the paper contributes to the collective effort of sharing field experiences for the benefit of other anthropologists.

Doing anthropology 'out of the corner of one's eye' stands both for a method and an attitude, worked out through the research process. It is a method of capturing something that is not discussed straightforwardly in the presence of the researcher, something that quickly turns from visible into invisible. It is an attitude in which discretion and respect mingle with diffidence. Moreover, it reflects the main idea of my project, namely that of collecting perspectives on faking and fakes which co-exist with the mainstream representations of brands. If one sees something out of the corner of one's eye, one sees it, but not clearly, because it happens to one's side. One has to grasp knowledge as it appears, in the form of 'flashes'. Benjamin (1999) would agree, and would encourage the researcher to imagine the intangible, the transient, the ephemeral, that which escapes formalised articulations, and to sense and follow that which is not stable, not re-articulable, but which momentarily shows itself. Unknowingly, I followed his advice.

\section{Seeing fakes, talking clothes}

I began my fieldwork with a walk in my hometown, in Romania, to reassure myself that there were fake branded goods in the local wardrobes. Soon I was to lose count. Then, I visited friends and relatives, announced my research topic, and attempted to elicit local definitions of fake brands.

The reactions were rather bitter. A young man, who wore a fake $\mathrm{C} \& \mathrm{~K}$ jacket during our meeting, reasoned that counterfeit is a cheaper version of a genuine garment and concluded: 'We wear these clothes! They suit us! They are cheaper and we can afford to buy them.' Another reckoned that counterfeited clothing 'lacks beauty and cannot be loved. You can feel whether you're wearing a genuine or a counterfeited garment. Well, maybe you only subconsciously realise this, otherwise you wouldn't attach importance to the matter.' An acquaintance virtually burst out: 'I can tell you what a fake is! They see an image and make something like it in a way that borders on the outrageous! But we have to compromise and go for something that is both beautiful and cheap. Truth be told, cheap things have invaded our market.' I was repeatedly warned not to use the word 'counterfeit'. 'You ought not to speak like this, many will 
say you scoff at them, no matter if they really wear counterfeits or not. Nobody is going to openly admit they wear fakes if you ask bluntly. People do not really use these words anyway. We just hear them on TV,' my mother insisted. Thus, to avoid criticism and rejection, I decided to declare a broad interest in clothing as an aspect of contemporary life.

Angry reactions still persisted as part of the field routine. 'You want to study how we dress in cheap clothes'; 'you want to write about how we dress in turcisme [goods made in Turkey] and chinezisme [goods made in China] from Europa'; 'we cannot afford good expensive clothes, like the branded ones, and you take us for people who lack taste in clothing'; 'I am trying to weave an image, you come to point out the cracks and remind me of the fluff!' Our shared background made people less tolerant of my curiosity about things they thought I should already understand or experiences I should already have had. The presumption was that I was pretending to be an observer when in fact I was a participant, having a vested interest in trivia, and that I would go on to expose and misuse the information (Bakalaki 1997).

These reactions were directed towards me as an ambivalent insider/outsider, whom they envisaged as turning her nose up at the things that predominated in the local clothing-scape, due to her different sartorial preferences and years spent in the capital city and abroad (and the attitude they imputed to me belonged to many locals too, as I was to discover). A certain 'cultural intimacy', that is, in Herzfeld's words (1997: 3), 'the recognition of those aspects of a cultural identity that are considered a source of external embarrassment but nevertheless provide insiders with their assurance of common sociality', became manifest in such comments. They helped me understand the importance locals attributed to clothing, the efforts they put and the pleasures they took in dressing well, expressed through idioms such as 'we might be poor but we are also proud' (săraci, dar fudui) and 'better not to have anything to put on the table than not to have anything to put on' (mai bine să nu aibă ce pune pe masă decât să nu aibă ce pune pe ei), or sărăcie cu luciu, a pun, difficult to translate into English, which literally means shabby or spurious wealth, coming from sărăcie lucie, dire poverty (for most of the inhabitants of this provincial town were far from well-to-do).

I set about investigating sources of clothing in local wardrobes, preferences, relationships to materiality and notions of quality, the dialectics between the aspirational and the actual, and the search for the normative in clothing choices. I engaged people in conversations about their wardrobes and dreams, witnessed gestures or paid attention to combinations of clothing as a shop assistant, a companion on shopping trips, a participant in friends' gatherings, a casual pedestrian in the market, and a visitor to shops. In most of my conversations, I included questions about fakes. I also registered any related details and spontaneous comments I happened to come across or provoke.

Many a time fake clothes and accessories turned out to be possessions that people were willing to talk about. Once it was a pair of blue jeans that a mother bought for her daughter, reasoning that the words written in rhinestones added the touch of glamour that a party outfit needed (the words were a brand name, so the seller said, assuring her that she had made an excellent choice, but she was not at all impressed; for her, the rhinestones were the most important part, and it was from this point of view that she introduced the story to the anthropologist). Or it was a pretty purse with a label reading Prada, bought from the market and previously used every day, but, since the day its owner found out, from the anthropologist, that the word was actually 
a brand name, used only for special occasions. At another time, it was a jogging suit, a cherished item, recently washed and placed on the chair the anthropologist was about to sit on, then carefully folded and placed in the wardrobe, where it would stay until the next holiday. It had been carefully kept like this for the last five years, since the day its owner went to a mountain resort and felt out of place without a jogging suit to wear while wandering the streets. He bought one on the spot, trying his best to select a quality Adidas suit, the brand which seemed the most popular in that place. He confessed to having wondered only once if this was an original or a copy, when he heard some children laughing at the obviously fake branded Nike cap of his elder neighbour. 'There must be imitations and imitations. Mine is a good one. If it hadn't been, I would have bought another one, for one has to be like the next man,' he explained, shrugging his shoulders.

At other times, the fake branded clothes were included in the stories people told me to make me understand local ways of relating to clothing. To give an example, a fake branded item appeared while my interlocutor was explaining the importance of clothing. First he recounted a failed attempt of passing as an orphan, and benefiting, thus, from travel concessions. He could not fool the ticket inspector with his fake card because he wore a good-looking jogging suit and trainers. As an aside, he added that the jogging suit was original, but not the trainers. During another meeting, I reminded him about this episode and asked if he had ever thought that the combination of an original and a copy might be problematic. He had not, they matched, they were both good looking; the problem was the difference in quality and its consequence, the fact that the jogging suit lasted while he had to buy one pair of trainers after another. Days later, he confessed to having thought about what I said.

I have never seen these things in that light. This is how matters stand here. These are the resources. If you pay a lot for the jogging suit, there is no money left for the shoes. You combine things, good and less good, things from the mall with things from the bazaar. And you don't tell people you did it. But - do you really think there are genuine things in this country? Even the malls sell counterfeits! I am buying [counterfeits], but not those recognizable from miles away. I am not a country boy who goes for the Chinese crap. I buy only good copies and choose them myself from Europa. And I can see no problem or reason to be ashamed of buying counterfeits. I am not the only one doing this.

In these examples, the fakes, recognized or not, declared or not, were either valued as 'affordable brands' and 'new clothing' or devalued as 'cheap things that have invaded our market', depending on persons and contexts.

In brief, efforts to explore the presence of fake branded clothing in local context(s), even out of the corner of my eye, had been rewarding, for there was many a time a chance to clarify the initial blurred images. They brought to the foreground fake branded clothing's oscillation between significant and insignificant, placing it within a larger clothing category, that of 'Europa' clothing, and proving its potential for opening windows to important aspects of local life, mostly to the production of taste as an act of (self-) differentiation (Bourdieu 1984). Owning brands or fakes, knowing brands or fakes, had been turned into different forms of cultural capital. 


\section{Wandering the market, observing unobtrusively}

I went to my second chosen field site, the 'Europa' market in Bucharest, not only to 'follow the fakes', but also to investigate the market as an important source of clothing. Since its opening in the early 1990s, the ever-expanding market has become one of the main sources of domestic materiality, integral to everyday life in Romania. After decades of 'imposed homogeneity' under the communist regime (Humphrey 2002), a different kind of homogeneity seems to have made its appearance.

To start off with I travelled to the market as the companion of a trader, who bought supplies for her shop from this place. These were rapid, guided explorations, almost always following the same route, and stopping at the same stalls. Thus I had a chance to observe how the trade worked and how the material offer of the market is turned into something fashionable through the combined efforts of traders and sellers. 'Don't be so reluctant, so provincial. I am telling you the Bucharesters, everyone buys this stuff. You don't have to like it, just tell your clients this is the latest fashion. The Chinese and the Turks know better than us what is fashionable. Well, don't tell them these are the only things one can buy here...'-remarks of a kind I often heard. My ethnographic self was not disclosed even once, for my informant, confronted with the curiosity of her acquaintances, decided on the spot that this would be beyond their comprehension, and worse, that it could jeopardise her hard-won relationships (and since she acquired most of her goods on credit, good relationships were a precious capital).

Then I ventured out on my own to (re)search the whole market, a babel of voices, a labyrinth of a few hectares, a huge network of narrow, rudimentary paved alleys with hundreds of stalls, surrounded by a few buildings, some tumble-down, others brand new, such as the red structures that make up the Chinese 'Red Dragon' commercial complex. The market is run by traders of different ethnicities, e.g. Turks, Arabs, Gypsies, Romanians, and Chinese. Moreover, it is a 'polluted' place (Douglas 1984), illustrating the 'disordered' nature of the postsocialist order (Bodnar 2004). 'The hotbed of business fraud', 'the battlefield of mafia clans', 'an absolute squalor', 'the lice house', 'the hovels', 'the paradise of indifference, smuggling, and the black market', 'poor people's supermarket', 'the bazaar', 'the illegal Europe', 'the other Europe', 'the Chinese Europe'- these were some of the expressions used to describe the market that I collected both from the media and from casual conversations.

I was not only lost in the hustle and bustle of the marketplace, but also rejected as a researcher. People working in this quasi-illegal place often had hostile attitudes towards me (journalists reported similar reactions). The few friendly traders pointed out that complicity in illegal activities 'place us all in the same pot', and being seen talking with me could be risky for them. As attempts to engage vendors in longer conversations failed, I changed my research strategy to an unassuming one, wandering the market for hours and days in a row, and then writing down, at home, moments objectified by my anthropological gaze. These were fleeting glimpses of a hectic world, caught while I was strolling through the alleys, stopping to look at this and that merchandise, eavesdropping and interviewing by comment (Snow and Anderson 1993, Hopper 1996). I pieced together various impressions, e.g. different ways of exploring the market, visitors' clothing, ways of selecting the goods, retorts, exclamations of delight or disappointment, until I felt I saturated in this experience.

Fakes represented only a tiny part of the material world I had traversed. They were less visible in the spring and early summer of 2006 and more visible in the summer of 
2007. During my first visits, I only caught sight of them from time to time, in exchanges that lasted but a second, whispered offers, goods kept under the counter, cautious inquiries; signs for me that they were there, but only for certain people. The next year, besides the usual instantaneous appearances, a whole section of the market was crowded with items made in Turkey, in stalls run by Gypsies. However, they were not advertised as brands, but as 'beautiful', 'good quality', 'cotton', 'identical copies made in Turkey, in the same workshops as the originals'. Their open presence illustrated, to my mind, the good position that the Gypsy vendors-members of the same clan from south of Bucharest-occupied in the power structure that kept this illegal place alive. This was a lucrative business, for many brand aficionados visited the stalls. The sellers, with their marketing strategy, consolidated a hierarchy of fakes, the Turkish ones being placed at the top. The 'real fakes' were the identical copies, the 'fakes' were the poorly made Chinese ones, they emphasised.

In addition to occasionally seeing the fakes, these visits allowed me to better understand the inclusion of fake brands in the category of 'Europa clothes', both of which carried connotations of deserving contempt, at least discursively. My way of doing research helped me to go beyond the discourse and to register the practices. In a bizarre sort of way, this place, the Europa market, seemed to stand for the cutting edge of the modern world, the underbelly of what is publicly acknowledged, but supporting the visible and the acknowledged. Petty traders and clients were 'extracting' things out of this symbolically polluted place, and then building respectable and fashionable appearances.

However, having more or less found an answer for the pressing question of what kind of ethnography was possible in a place like this, and even coming up with a label for it, that is, anthropology out of the corner of my eye, I further asked myself what kind of ethnography was permissible. Was the unobtrusive observation within the public space of the market ethical? How should I construct my identity? How and to whom should I declare my research interest? An incident abruptly interrupted this line of thinking. While I was prowling about, I stopped a pickpocket from opening the bag of an elderly woman and then heard someone angrily commenting: 'I saw this one before, she wanders around without buying anything.' I realised that I wasn't an anonymous customer anymore. Believing in the quality of my observations, and taking comfort from Marcus' (1995:100) point about the inevitable variability of the accessibility of the research at different sites in a multi-sited project, I decided to leave this research site.

\section{Chasing fakes, demanding to know}

In midsummer 2006, I moved to Istanbul. The first months were rather disconcerting. In this huge city, fake branded clothes, footwear and accessories of different degrees of similitude and quality caught my eye many times a day: waved by street vendors; crammed into a covered footway in Kadiköy; displayed in the window of a newly opened shop in Cayırbaşı; welcoming thousands of visitors to the Grand Bazaar, where they held the same power of attraction, some would say even bigger, as traditional jewellery or carpets; drying in the sun on a balcony in a poor neighbourhood, Zeytinburnu; carefully wrapped and piled up on the stalls of a weekly market, sober competitors to the wildly rummaged heaps of defolu (second-hand officially branded goods); piled on the floors of the showrooms in the most thriving textile district, Merter, waiting for their foreign bulk customers; making glamorous 
appearances in the shop windows of Laleli; protected by darkness on the quays of Eminönü; hidden in the side passages of Beyoğlu.

I spent a lot of time hanging around bazaars and textile districts, experiencing not only moments of aesthetic delight in front of the exuberant touches added to original models, or unconditioned sympathy for those who trembled next to piles of poorly made imitations in side alleys and on cold quays, but also times of despair and touches of alarm, when I fully acknowledged the danger of being too curious and the dark side of counterfeiting. I travelled several times between Istanbul and Bucharest by bus, accompanying petty traders, again eavesdropping and interviewing by comment, again observing unobtrusively ways of crossing the borders with (decent) quantities of fake branded goods (their owner being required to contribute more to the collective amount used to bribe the Bulgarian custom officers and left alone to deal with the Romanian Fraud Squad if the bus was stopped on the way to Bucharest).

The fakes were ubiquitous, and everyone seemed to know what was going on but turned a blind eye (the state and its institutions, lawyers and police, textile producers and distributors), even common people were in possession of bits of information, everyone but the anthropologist. And so I talked about my research intent with everyone, hoping some connections would be forged. People whispered everyone might produce counterfeits, not only the small workshops, but also big companies, the two types of production being inextricably intertwined within the subcontracting chains of the textile industry. They were unanimously of the opinion that the production was pushed more and more into secluded and secured places by the current stricter legislation, but that, despite raids and attempts at enforcing the law, the business was thriving, urging people to be more creative and more ready for any type of action in order to avoid encounters with the agents and institutions working to limit their activity. But most of these conversations ended with conspiratorial winks, shrugs, distrustful glances, knitted eyebrows, or disbelief.

The problem lay in convincing acquaintances that I was conducting a study and in explaining what use the information was to others and to them (it would bring deeper understanding that challenged conventional beliefs, I used to say, for example, wondering at the same time how well or for how long my discourse was understood). I also had my competitors, the so-called 'brand agents', usually former police officers who infiltrated the trade and sold information about production and distribution locations to lawyers. Nevertheless, the fact that I was a foreigner, non-western, and worked with an interpreter for some time was turned to my advantage, since it diluted some of this suspicion, set me apart from the brand agents, and, even more importantly, impressed my interlocutors. I changed my introductory lines, emphasising that I was interested mainly in the arguments, feelings and stories of people involved in this trade, whose voices are rarely heard. From 'follow the thing', I had to move to 'follow the life' (Marcus 1995).

'People know each other, they cover each other. From where would you start the unraveling? Which thread would you pull first? Do you realize there are hundreds of workshops that can produce fakes?' Such rhetorical questions were put to me, while those who uttered them nevertheless tried to help me, introduced me to people they knew, even scoured textile districts for acquaintances of theirs involved in the counterfeiting trade. Sometimes, we could not find the persons we were looking for, as the industry is very dynamic - some make it big, others go bankrupt. At other times we were able to engage workshop owners in short conversations, most of them 
recounting personal reasons for 'mixing white and black' in their production and mentioning strategies for avoiding being caught, while stressing that many others were doing the same, basic survival. A few ventured to show how a counterfeit was made in the workshop. More sent us to their neighbours, for they were the ones definitely doing such things.

I found myself in the awkward position of asking questions in a milieu where people do not ask each other too much, for a trusted sponsor is enough to put them in contact (and, ironically, I was always asked to have precise questions; several times when my interlocutors stopped in the middle of a conversation and wondered if I really found what they were telling me of any use, a reply of 'anything is fine, for I don't know many things anyway' was the worst answer!). There were many other reasons to worry. What kind of fieldwork was I doing, seeing this world as though through a thick veil, not really taking part in it? Who was I to demand to know? By simply gazing at the facades, stubbornly knocking on the doors, collecting bits from the few who were willing to talk, wandering around the city, taking snapshots, writing down rumours and tricks that people thought I wanted to hear about, would I end up by knowing this hidden world?

Then, one day, I felt the real fieldwork started, in a bazaar shop crammed full of fake branded underwear, in which I was allowed to come and stay anytime, for as long as I wanted, for three months. 'Don't be shy, come whenever you want, I have nothing to hide, kardeşim [my brother/sister]', I was told. So I began to learn about the daily life of an imitasyoncu, about the way he obtained the goods he was trading in, whether producing or buying them from the local textile market, and about what it means to conduct a fluid business, moreover one that infringes the law. I was surrounded by an array of commodities that blurred the distinction between original and fake: identical copies, for 'effort must be put into making frauds too'; not-so-identical copies, for those interested in the names only; damaged products and end-of-line clothing transformed into fakes by stamping brand names or sewing labels on them; leakages from the official production; overstock of genuine brands sold off on the local market; and models created on the spot by traders who knew the local taste better and improved original models. I wondered every day what a fake was, and still ponder what the proper answer to this question might be — or indeed if this is a good question.

Partners, other traders and regular customers dropped by all the time, and my host did not miss a chance to present himself as a successful trader. In those moments, his tongue could not be stopped: his numerous clients, the high-tech factory, the clever way in which his business was organised, the quality of the products, the models, the brands, all eddied around in those torrents of words. As for me, I was introduced as a friend and student from London who would write about imitations, and I was allowed to take part in these conversations. My nascent Turkish prevented me from fully understanding the conversations and lessened some worries (only a few times did I have to wait outside the shop till the meeting was over). I was thus again practicing anthropology out of the corner of my eye.

\section{Out of the corner of my eye}

The anthropological mode of knowing is relational and performative, that is, gained through social relationships and through living and performing our role(s) in a social world (Hastrup 2004). However, there are cases in which being allotted a role or the 
role one wants is less likely to occur. The anthropologist who gradually realises this is not always in a comfortable position.

The anthropologist is, almost by definition, transient, and as a result it is at least as difficult for the people we work with to establish ties with us as it is for us to do the same. And I was more transient than usual. I was conducting multi-sited research, moving between sites, shifting affinities for, affiliations to, finding myself with 'all sorts of cross-cutting and contradictory personal commitments' (Marcus 1995:113). Moreover, my method of hanging out and catching things out of the corner of my eye seemed to send me in the opposite direction, that is, towards a lack of commitment, detachment, forcing me to constantly ponder the dangers of 'understay' and 'overstay', my mood vacillating between 'I am not committed' on the one hand, and 'I am too committed; I should not look too committed' on the other hand.

Nevertheless, there were instances in which commitment was something that I felt I accomplished, some people believing in my sincere academic interest in their lives, my open attitude towards fakes and faking, and my positioning on their side. In my hometown, it was a shopkeeper, one of the numerous poor, the main character of the informal economies (Chelcea and Mateescu 2004). She allotted me the role of companion, and we whiled away many hours as I listened to her stories and curiosities. I watched her, morning after morning, hanging a discoloured Dolce \& Gabanna t-shirt in the window of her rather shabby small shop, in the hope that she would attract younger, fashion-conscious customers, people with more money and interest in clothing than her usual clientele. The fake brand seemed to magically transform into the stuff that made her keep going in times of despair.

In Istanbul, it was an imitasyoncu, someone who admits to turning the making and selling of fake brands into a profession, who allotted me the role of documenting his honesty, and addressing, on his behalf, a question to my future audience, that is: 'Isn't it a crime to sell what cost you $2 €$ for $40 €$ ? Or is it a crime to sell it for $3 €$ ?' It was an instance of the "complicity of mutual interest between anthropologist and informant, subtly but clearly understood by each other, that makes rapport possible - indeed that constitutes, even constructs it' (Marcus 1997:89), for I met him while he was recovering from a lawsuit that had a negative impact on his business. He struggled, like the fieldworker herself, to produce meaningful statements and acts in a world scored with contingency and potential incomprehension (Bowman 1998, Hendry 2007:593). He was the one who taught me to think of trading in fake brands as a niche with much smaller oscillations between conventional morality and illegality, which allows one to earn money and confirm one's own individuality. In his case- the son who graduated from a religious school, rebelled against the patriarch, lived on the streets and then established himself as a respected trader in fake branded goodsthese goods objectify the balance he has constructed between conformity/legality and individuality/illegality.

Moreover, unlike Marcus' multi-sited ethnographer (1995:113), who solves the problem of contradictory committments by being an activist and energetically renegotiating his or her identity, I had my moments of fatigue and found refuge and reward in practicing anthropology out of the corner of my eye. I was not looking at things from above or 'nowhere', as detachment implies, but from one side, discreetly. Instead of immersing myself into social worlds, I found myself hanging around, being here and there, grasping knowledge as it appeared, but also provoking its appearance in glimpses. 
In frantic attempts to save my active self, I clung to the 'business of research' (Clifford 1988:102). I rarely recorded conversations verbatim and seldom took notes in the presence of my informants. I gleaned most of the information from low-key interactions and collected ethnographic details by dropping by here and there, strolling into markets, memorising gestures, witnessing single events. I strove to objectify my own subjective status, bringing to the foreground what I had in common with my interlocutors, ranging from clothing preferences to common background or non-western identity, 'in the hope that a sort of complicity/spontaneous empathy will make the outsider the desired anthropological insider' (Marcus 1997:89).

In Istanbul, I was told that the act of faking a brand is like a 'spark' (klvılcum gibi). This is a pertinent image, suggesting the ephemeral, the intangible, the transient that was so central to my fieldwork (fakes are fakes only in the eyes of certain people, fakes are present only for some people, fakes happen and die out). Practicing anthropology out of the corner of one's eye allows one to catch some of the sparks.

\section{References}

Appadurai, Arjun. 1986. Introduction: Commodities and the politics of value. In The social life of things: Commodities in cultural perspective (ed.) Arjun Appadurai, 3-63. New York: Cambridge University Press.

Bakalaki, Alexandra. 1997. Students, natives, colleagues: Encounters in academia and in the field. Cultural Anthropology 12(4), 502-526.

Baudrillard, Jean. 1983. Simulations. New York: Semiotext(e).

Benjamin, Walter. 1999. Theses on the philosophy of history. In his Illuminations, 245-255. London: Pimlico.

Bodnar, Judit. 2004. Asamblând piața: Transformările sociale ale spaţiului public şi sfârşitul iluziilor despre economia secundară în Budapesta postsocialistă [Assembling the market: The social transformations of the public space and the end of illusions about the secondary economy in postsocialist Budapest]. In Economia informală în România: Piețe, practici sociale şi transformări ale statului după 1989 [Informal economy in Romania: Markets, social practices and transformations of the state after 1989] (eds.) Liviu Chelcea and Oana Mateescu, 189-222. Bucureşti: Paideia.

Bourdieu, Pierre. 1984. Distinction. London: Routledge \& Kegan Paul.

Bowman, G. 1998. Radical empiricism: Anthropological fieldwork after psychoanalysis and the Année Sociologique. Anthropological Journal on European Cultures 6(2), 79-107.

Chelcea, Liviu and Oana Mateescu (eds). 2004. Economia informală în România: Piețe, practici sociale şi transformări ale statului după 1989 [Informal economy in Romania: Markets, social practices and transformations of the state after 1989]. Bucureşti: Paideia.

Clifford, James. 1988. The predicament of culture: Twentieth-century ethnography, literature, and art. Cambridge, MA, and London: Harvard University Press.

Douglas, Mary. 1984. Purity and danger: An analysis of the concepts of pollution and taboo. London: Ark. 
Douglas, Mary and Isherwood, Baron. 1979. The world of goods: Towards an anthropology of consumption. London: Allen Lane.

Eco, Umberto. 1986. Travels in hyperreality. In his Travels in hyperreality: Essays, 358. San Diego: Harcourt Brace Jovanovich.

Hastrup, Kirsten. 2004. Getting it right: Knowledge and evidence in anthropology. Anthropological Theory 4(4), 455-472.

Hendry, Joy. 2007. Building bridges, common ground, and the role of the anthropologist. Journal of the Royal Anthropological Institute 13, 585-601.

Herzfeld, Michael. 1997. Cultural intimacy: Social poetics in the nation-state. New York, London: Routledge.

Hopper, Kim. 1996. Fresh thickets of trouble: Unresolved ethical issues of research in the urban public domain. City \& Society 8, 155-172.

Humphrey, Caroline. 2002. The unmaking of Soviet life: Everyday economies after socialism. Ithaca and London: Cornell University Press.

Kalir, Barak. 2006. The field of work and the work of the field: Conceptualising an anthropological research engagement. Social Anthropology 14(2), 235-246.

Kopytoff, Igor. 1986. The cultural biography of things. In The social life of things: Commodities in cultural perspective (ed.) Arjun Appadurai, 64-94. New York: Cambridge University Press.

Marcus, George E. 1995. Ethnography in/of the world system: The emergence of multi-sited ethnography. Annual Review of Anthropology 24, 95-117.

---------. 1997. The uses of complicity in the changing mise-en-scène of anthropological fieldwork. Representations 59, 85-108.

Snow, D.A. and Anderson, L. 1993. Down on Their Luck. Berkeley: University of California Press.

\section{About the author}

Magdalena Crăciun is currently writing her $\mathrm{PhD}$ thesis at University College London on fake brands in the margins of Europe. Her research interests include material culture, post-socialism, cultural history of fakes and anthropology of branding. She can be contacted at e.craciun@ucl.ac.uk 